\title{
Efektivitas Pengembangan Modul Berbasis Konstruktivisme Pada Mata Pelajaran Sistem Komputer Bagi Siswa TKJ Tingkat SMK
}

\author{
Widya Darwin \\ Program Pascasarjana, Universitas Negeri Padang \\ widyadarwin97@gmail.com \\ Ridwan \\ Program Pascasarjana, Universitas Negeri Padang \\ Ridwan32@gmail.com \\ Ahyanuardi \\ Program Pascasarjana, Universitas Negeri Padang \\ Ahyanuardi@gmail.com
}

\begin{tabular}{l} 
A R T I C L E I N F O \\
\hline Article history: \\
1 Januari 2020 Received in \\
revised form \\
30 Mei 2020 \\
Accepted 30 Juni 2020 \\
Available online \\
15 Juli 2020 \\
\hline Kata Kunci: \\
Efektivitas, Modul, \\
Konstruktivisme \\
Keywords: \\
Effectiveness, Modules, \\
Constructivism
\end{tabular}

\begin{abstract}
ABSTRAK
Permasalahan yang terdapat pada penelitian in adalah buku/sumber belajar yang disediakan kementrian sampai sekarang belum memadai disekolah, siswa kurang mandiri dan aktif dalam proses pembelajaran, guru dianggap satusatunya sumber dalam proses belajar mengajar, pemilihan media pembelajaran yang kurang sesuai menyebabkan siswa cepat bosan dan tidak mendengarkan guru, siswa belum dihadapkan pada situasi yang lebih nyata dalam proses belajar mengajar dan belum tersedianya modul pada mata pelajaran dasar- dasar kelistrikan di SMK N 1 Painan. Tujuan penelitian yaitu: 1) Mengembangkan modul pembelajaran
\end{abstract} Sistem Komputer untuk siswa kelas X Teknik Komputer Jaringan di SMKN 1 Painan, 2) Menghasilkan modul berbasis konstruktivisme untuk mata pelajaran Sistem Komputer yang valid, praktis dan efektif. Metode penelitian yang digunakan adalah research and development dengan model pengembangan ADDIE yaitu analysis, design, development, implementation, dan evaluation. Hasil penelitian menunjukkan bahwa: 1) Modul pembelajaran Sistem Komputer berhasil dikembangkan melalui model pengembangan ADDIE, 2) Modul pembelajaran berbasis konstruktivisme yang dihasilkan sudah efektif diterapkan pada siswa kelas X di SMKN 1 Painan. 
2) The constructivist-based learning module produced was effectively applied to class $X$ students at SMKN 1 Painan.

\section{PENDAHULUAN}

Pembelajaran merupakan interaksi antara guru dan siswa dimana seorang guru dapat mengarahkan dan membimbing siswa untuk belajar melalui berbagai cara. Cara yang digunakan guru dalam proses pembelajaran dapat mempengaruhi berhasilnya proses pembelajaran itu sendiri. Abdi (2013) menyatakan bahwa kegiatan pembelajaran di kelas akan berhasil jika dapat dikendalikan dengan baik oleh guru dengan cara memberikan layanan belajar yang berkualitas pada siswa. Oleh karena itu guru dituntut untuk mampu memberikan suasana belajar yang berkualitas agar materi pembelajaran dapat dikuasai dengan baik oleh siswa. Berkenaan dengan hal tersebut, Ahmad (2011) menyatakan bahwa pembelajaran merupakan upaya mempersiapkan siswa agar mampu hidup di masyarakat. Maka dapat disimpulkan bahwa proses pembelajaran itu lebih ditekankan pada kegiatan belajar siswa yang telah diciptakan dan dipersiapkan oleh guru. Guru dituntut untuk tetap dapat mengemas pembelajaran yang berorientasi pada aspek sikap, pengetahuan, dan keterampilan dalam menunjang proses pembelajaran dengan memperhatikan metode pembelajaran, modul yang digunakan, serta kepribadian dan karakteristik siswa, agar tujuan pembelajaran dapat dicapai.

Tantangan dalam pembelajaran sebenarnya terletak pada proses pembelajaran, karena pada saat inilah akan muncul permasalahan. Kadang-kadang dalam proses pembelajaran terjadi kegagalan komunikasi. Materi pelajaran atau pesan yang disampaikan guru tidak dapat diterima siswa dengan optimal, artinya tidak seluruh materi pelajaran dapat dipahami dengan baik oleh siswa. Usaha pemerintah agar SMK mampu melakukan tugasnya terlihat dari berbagai upaya dalam berbenah kurikulum, yang saat ini sedang sibuk melakukan sosialisasi, menerapkan Kurikulum 2013 di SMK. Pelaksanaan Kurikulum 2013 menuntut kemampuan guru dalam penguasaan konsep esensial dan kemampuan pedagogik guru. Kurikulum 2013 menekankan pada domain sikap (spiritual, sosial), domain pengetahuan dan domain keterampilan. Ketiga aspek ini selanjutnya akan menjadi dasar untuk penyusunan Kompetensi Inti (KI) dan penjabarannya menjadi Kompetensi Dasar (KD).

Pola pikir yang ada dalam penyempurnaan Kurikulum 2013 saat ini sangat sesuai dengan karakteristik pembelajaran di SMK, yang diantaranya: penguatan pola pembelajaran yang berpusat pada siswa; penguatan pola pembelajaran interaktif (interaktif guru, siswa, masyarakat, lingkungan alam, sumber/media lainnya); penguatan pola pembelajaran secara jejaring (siswa dapat menimba ilmu dari siapa saja dan dari mana saja yang dapat dihubungi serta diperoleh melalui internet); penguatan pola belajar sendiri dan kelompok (berbasis tim); penguatan pembelajaran berbasis multimedia; penguatan pola pembelajaran berbasis klasikal-massal dengan tetap memperhatikan pengembangan potensi khusus yang dimiliki setiap siswa; penguatan pola pembelajaran ilmu pengetahuan jamak (multidisciplines); dan penguatan pola pembelajaran kritis. Besarnya tuntutan pelaksanaan Kurikulum 2013 diupayakan oleh pemerintah tidak membebani guru sebagai tenaga pengajar.

Berdasarkan pengamatan awal yang dilakukan di SMKN 1 Painan, pada saat proses pembelajaran sedang berlangsung, diketahui bahwa dalam menyampaikan materi 
pelajaran, guru melakukannya dengan menggunakan buku dan handout sebagai bahan ajar. Dalam pelaksanaannya, proses pembelajaran yang tejadi masih terpusat pada guru, siswa terlihat tidak aktif dan kurang mandiri dalam pembelajaran. Siswa hanya diam dan mendengarkan guru memberikan pelajaran tanpa ada tanggapan ataupun pertanyaan dari siswa. Disamping itu, melalui wawancara yang dilakukan terhadap guru mata pelajaran Sistem Komputer, terungkap bahwa mata pelajaran Sistem Komputer masih dianggap sebagai suatu mata pelajaran yang dianggap sulit dipahami oleh siswa.

Berkaitan dengan hasil belajar, Anwar (2010) menyebutkan bahwa suatu kelas dikatakan tuntas belajarnya (berdasarkan ketuntasan klasikal) jika dalam kelas tersebut terdapat $85 \%$ siswa yang telah tuntas belajarnya. Dari data yang hasil belajar yang telah dikumpulkan menunjukkan siswa yang sudah memenuhi KKM, lebih dari 58\% siswa pada kelas X TKJ berada di bawah dan 41,18\% lainnya memperoleh nilai 78 dan di atas 78 berdasarkan KKM yang telah ditetapkan yaitu 78 . Teridentifikasi bahwa penguasaan siswa terhadap kompetensi dasar berpasangan 3.3, 4.3, 35 dan 45, masih bermasalah karena belum sesuai antara yang diharapkan dengan kenyataan yang ditemukan di lapangan. Dengan kata lain, tujuan pembelajaran yang hendak dicapai masih ada yang belum bisa dicapai oleh siswa.

Berdasarkan fenomena yang terjadi dilapangan, maka dicari solusi agar siswa mampu memahami lebih dalam materi dalam pembelajaran dengan baik. Salah satu cara menciptakan suasana belajar agar siswa dapat belajar secara aktif dan mandiri yaitu dengan menggunakan modul. Setiyadi, dkk (2017) menyatakan bahwa penggunaan modul dalam proses pembelajaran bersifat praktif sehingga berpotensi mendapatkan respon positif sehingga dapat meningkatkan hasil belajar siswa. Sriwahyuni (2019) juga menyatakan bahwa bahan belajar modul mendapatkan respon yang sangat baik karena praktis digunakan dalam proses pembelajaran. Pada kesempatan yang lain, Sa idah \& Yulistianti (2018) juga menyatakan bahwa modul efektif digunakan sebagai bahan ajar yang dapat meningkatkan hasil belajar siswa.

Strategi pengorganisasian materi pembelajaran menggunakan modul mengarahkan pada upaya untuk menunjukkan kepada siswa keterkaitan antara fakta, konsep, prosedur dan prinsip yang terkandung dalam materi pembelajaran. Strategi pengorganisasian materi pembelajaran terdiri dari tiga tahapan proses berpikir, yaitu pembentukan konsep, intepretasi konsep, dan aplikasi prinsip. Strategi-strategi tersebut memegang peranan sangat penting dalam mendesain pembelajaran. Kegunaannya dapat membuat siswa lebih tertarik dalam belajar, siswa secara otomatis belajar sehingga dapat meningkatkan hasil belajar. Penelitian yang dilakukan oleh Gita, Samara, dkk 2018) juga menyatakan penggunaan modul dapat meningkatkan respon siswa dalam belajar dengan persentase 97,76\%. menyatakan bahwa modul sangat praktis digunakan belajar sehingga mempengaruhi hasil belajar siswa.

Pemilihan modul ini disesuaikan dengan karakteristik dan kemampuan serta kondisi kelas. Modul adalah bahan ajar yang bersisi tentang materi, metode, batasan-batasan dan evaluasi yang disusun secara sistematis dan menarik. Modul mampu digunakan secara mandiri karena di dalam modul terdapat contoh yang mendukung kejelasan materi, terdapat soal latihan dan tugas, terdapat rangkuman dan evaluasi (Self Instructional). Materi pembelajaran yang terdapat dalam modul dikemas dalam unit kegiatan yang utuh, sehingga memudahkan dipelajari secara tuntas (Self Contained), modul memiliki karakteristik Stand Alone yaitu modul tidak tergantung pada media lain, sesuai dengan perkembangan ilmu 
pengetahuan dan teknologi serta fleksible (Adaptif) dan bersahabat dengan penggunanya (User Friendly), membantu kemudahan pemakai untuk merespon dan diakses. Komponen pada modul harus dikemas menarik sehingga dapat merangsang peserta didik untuk berpikir (Kolin, dkk, 2018). Selain itu juga pemilihan modul ini dikarenakan dengan menggunakan modul siswa dapat belajar dan memahami materi sesuai dengan kecepatan masing-masing.

Adapun kelebihan modul yang akan peneliti buat yaitu memiliki perpaduan materi pembelajaran dan gambar yang akan menambah daya tarik bagi peserta didik. Disamping itu, pendekatan pembelajaran yang bisa membuat siswa mampu untuk lebih mendalami materi dan mangkonstruk pengetahuan mereka adalah dengan menggunakan modul berbasis konstruktivisme. Pembelajaran berbasis Konstruktivisme adalah pembelajaran yang mengharuskan siswa untuk aktif dalam pembelajaran dengan mengembangkan pemikiran sendiri, menemukan sendiri dan mengkonstruksi sendiri pengetahuan dan keterampilan barunya, dimana dalam pembelajaran ini guru hanya berperan sebagai fasilitator.

Terkait dengan pemilihan modul berbasis konstruktivisme ini, penelitian yang dilakukan Arifin (2011) dengan pengembangan modul evaluasi berbasis konstruktivisme menunjukkan hasil penelitian yaitu melalui modul evaluasi pembelajaran yang dikembangkan menggunakan teori konstruktivisme menunjukkan terdapat peningkatan kemampuan peserta didik dalam memahami konsep materi evaluasi pembelajaran, kemampuan peserta didik dalam mengembangkan lembar observasi, soal dan rubric soal baik essay, maupun objektif.

Berdasarkan beberapa masalah yang telah dikemukakan di atas, maka dikaji penelitian mengenai "Efektivitas Pengembangan Modul Berbasis Konstruktivisme Pada Mata Pelajaran Sistem Komputer Bagi Siswa TKJ Tingkat SMK" ini dilakukan.

Tujuan penelitian ini yaitu: 1) Mengembangkan modul pembelajaran Sistem Komputer untuk siswa kelas X Teknik Komputer Jaringan di SMKN 1 Painan, 2) Menghasilkan modul berbasis konstruktivisme untuk mata pelajaran Sistem Komputer yang valid, praktis dan efektif. Kebaruan penelitian ini dibandingkan penelitian sebelumnya adalah penggunaan tipe belajar konstruktivisme ke dalam modul yang dikembangkan. Sehingga siswa dapat mengeksplorasi kemampuan yang dimilikinya secara utuh.

\section{METODE}

Metode Penelitian ini, menggunakan jenis metode penelitian dan pengembangan (Research and Development). Daryanto (1993) Research and Deveelopment $(R \& D)$ yaitu suatu proses atau langkah-langkah untuk mengembangkan suatu produk yang ada, yang dapat dipertanggung jawabkan. Menurut Herman (2012) Penelitian R\&D juga dapat diartikan dengan metode penelitian dan pengembangan merupakan metode penelitian yang digunakan untuk menghasilkan produk tertentu dan menguji keefektifan produk tersebut.

Penelitian ini bertujuan untuk mengembangkan modul berbasis konstruktivisme melalui langkah-langkah yang sistematis untuk kemudian diuji kelayakannya. Penelitian ini merupakan penelitian pengembangan model ADDIE yaitu Analysis, Design, Development, Implementation, dan Evaluation. 
Penelitian dilaksanakan di SMKN 1 Painan terhadap siswa kelas X. Jumlah siswa yang menjadi sampel dalam penelitian ini berjumlah 31 orang siswa. Teknik pengumpulan data yang digunakan adalah data primer dan data sekunder. Instrumen penelitian yang digunakan adalah angket dan soal. Teknik analisis data yang digunakan adalah ketuntasan klasikal dan uji gain score.

\section{HASIL DAN PEMBAHASAN}

\section{HASIL}

Efektifitas penggunaan modul pembelajaran berbasis konstruktivisme ditinjau dengan dua cara yaitu melihat ketercapaian Kriteria Ketuntasan Minimum (KKM) secara klasikal dan dengan menbanding data pretest dan posttest degan menggunakan analisis gain score. Ketuntasan klasikal dilihat dari persentase jumlah siswa yang tuntas (membandingkan nilai KKM yang ditetapkan yaitu 75) setelah menggunakan modul pembelajaran berbasis konstruktivisme. Dasar untuk menentukan efektivitas modul pembelajaran berbasis konstruktivisme adalah jika persentasi ketuntasan klasikal siswa lebih besar atau sama dengan $85 \%$ maka modul pembelajaran berbasis konstruktivisme efektif digunakan. Jika sebaliknya, persentasi ketuntasan klasikal siswa lebih kecil dengan 85\% modul pembelajaran berbasis konstruktivisme tidak efektif digunakan. Berikut hasil rata-rata nilai siswa pada mata pelajaran Sistem Komputer yang disajikan pada Tabel 1.

Tabel 1. Ketuntasan Klasikal

\begin{tabular}{lccccc}
\hline No & Jumlah & \multicolumn{4}{c}{ Hasil Belajar } \\
\cline { 3 - 6 } & Siswa & Tidak Tuntas & \% & Tuntas & \% \\
\cline { 3 - 6 } 1 & 31 & 1 & 3,225 & 30 & 96,775 \\
\hline
\end{tabular}

Berdasarkan hasil analisis yang diuraikan pada Tabel 1, maka diperoleh ketuntasan siswa sebesar 96,775\%. Hal ini menunjukkan ketuntasan klasikal telah tercapai, dapat disimpulkan bahwa modul pembelajaran berbasis konstruktivisme efektif digunakan jika ditinjau dari ketuntasan klasikal.

Peningkatan hasil belajar siswa setelah pretest dan postest dilakukan perhitungan dengan gain score. Modul pembelajaran berbasis konstruktivisme dikatakan efektif jika nilai gain score yang didapat $\geq 0,7$ atau berada pada kategori tinggi. Nilai gain score yang diperoleh yaitu 0,791 yang berada pada kategori tinggi. Hasil analisis gain score dapat dilihat pada tabel 2 .

Tabel 2.. Rekapitulasi Nilai Gain Score

\begin{tabular}{cccc}
\hline $\mathbf{N}$ & Nilai Minimum & Nilai Maksimum & Gain Score \\
\hline 31 & 0,547 & 1,000 & 0,791 \\
Kategori & & & Tinggi \\
\hline
\end{tabular}

Berdasarkan ketuntasan klasikal yang mencapai $96,775 \%$ dan nilai gain score 0,791 dengan kategori tinggi maka dapat disimpulkan bahwa modul pembelajaran berbasis konstruktivisme yang dikembangkan dinyatakan efektif.

Pengembangan modul pembelajaran berbasis konstruktivisme pada mata pelajaran Sistem Komputer untuk siswa kelas X TKJ di SMKN 1 Painan ini adalah serangkaian 
proses atau kegiatan yang dilakukan untuk menghasilkan modul pembelajaran berbasis konstruktivisme berdasarkan teori pengembangan. Tujuan pengembangan modul pembelajaran berbasis konstruktivisme ini adalah untuk menghasilkan modul pembelajaran yang efektif. Modul pembelajaran yang dikembangkan ini berbasis pada model pengembangan ADDIE, yang terdiri dari tahap analisis (analysis), desain (design), pengembangan (development) implementasi (implementation), dan evaluasi (evaluation) (Karli, 2003)

Berdasarkan pengujian efektivitas modul pembelajaran berbasis konstruktivisme melalui ketuntasan klasikal dan gains score. Mengukur tingkat efektivitas penggunaan modul pembelajaran berbasis konstruktivisme yang dikembangkan. Pedoman pengukuran dilihat dari presentase nilai ketuntasan hasil belajar yang diperoleh siswa setelah selesai melaksanakan pembelajaran dengan menerapkan modul pembelajaran berbasis konstruktivisme. Nilai presentase ketuntasan hasil belajar siswa diperoleh berdasarkan kegiatan ujian (test) yang dilaksanakan pada pertemuan terakhir kegiatan pembelajaran. Berdasarkan pengujian gain score, diperoleh nilai sebesar 0,791 dengan interpretasi tinggi. Maka dapat disimpulkan bahwa modul pembelajaran berbasis konstruktivisme dinyatakan efektif.

\section{PEMBAHASAN}

Seperti yang telah dijelaskan pada pemaparan hasil, terbukti bahwa modul pembelajaran berbasis konstruktivisme dinyatakan efektif dalam meningkatkan hasil belajar siswa. Penelitian ini turut mempertegas peran modul berbasis konstruktivisme dalam proses pembelajaran.

Penelitian yang dilakukan sebelumnya yaitu penelitian yang dilaksanakan oleh (Mulyana, dkk, 2015) mengenai model pembelajaran konstruktivisme menggunakan modul. Penelitian ini diadakan di SMAN 1 Padang dan SMAN 9 Padang. Penelitian ini dilaksanakan pada pembelajaran Kimia, hasil penelitian menunjukkan bahwa model pembelajaran konstruktivisme menggunakan modul merupakan bagian dari pelayanan unggul yang dapat meningkatkan hasil belajar siswa baik disekolah unggul maupun disekolah tidak unggul. Ariana, dkk, (2020) menyatakan bahwa modul dapat meningkatkan ketrampilan literasi ilmiah dan hasil belajar siswa. Suryanda, dkk, (2016) menyatakan bahwa modul dapat membantu siswa dalam memahami materi pembelajaran dengan baik.

Dibalik dari keefektifan tersebut sala satunya dikarenakan oleh ke -valid-an dari modul yang dibuat. Terkait dengan hal ini, Penelitian yang dilaksanakan oleh Karwono (2017) tentang pengembangan perangat pembelajaran kimia SMA kelas XI IPA pada materi larutan berorientasi pembelajaran konstruktivisme (Tesis) menegaskan bahwa perangkat yang dikembangkan harus valid menurut pakar dan pengguna (guru dan siswa). Ditunjang dengan penelitian lain yang dilaksanakan oleh (Azwar, 2012) tentang pengembangan perangkat pembelajaran kimia SMA kelas XI IPA pada materi larutan berorientasi pembelajaran konstruktivisme yang memperoleh hasil bahwa perangkat yang dikembangkan sudah valid menurut pakar dan pengguna (guru dan siswa).

Secara tradisional cara memperoleh pengetahuan dapat diartikan sebagai segala upaya yang dilakukan untuk mendapatkan informasi yang dapat ditemukan lewat lingkungan atau suatu peristiwa yang terjadi di lingkungan, dimana siswa mampu mengidentifikasi dan menyimpan infromasi tersebut sebagai pengetahuan mereka. Proses ini uga dapat disebut sebagai pengalaman. Unsur komunikasi pada proses belajar adalah 
salah satu unsur penting sehingga informasi dapat tertransfer pada siswa. Dalam beberapa level, pola mendapatkan informasi seperti ini dapat berjalan dengan baik, dalam waktu yang bersamaan guru berusaha agar siswa mengulang informasi yang memang harus mereka ketahui. Pola ini menyebabkan siswa harus belajar dari pengetahuan yang diberikan guru saja dan tidak berusaha untuk memahami konsep pelajaran yang mereka pelajari. Hal ini mengakibatkan pembelajaran kadang terjadi dan kadang tidak terjadi.

Pembelajaran yang kompleks dapat dianalisa dari rangkaian spesifik item yang dikomunikasikan, walaupun hal ini akan dipelajari atau tidak. Apabila komunikasi gagal, maka pembelajaran tidak terjadi dan tidak ada perubahan pengetahuan siswa. Pola pembelajaran seperti ini sangat terbatas, jika siswa memahami makna ide informasi yang disampaikan maka informasi tersebut akan menjadi pengetahuan pribadi siswa dan proses pembelajaran terjadi. Sebaliknya jika pembelajaran berlangsung tanpa proses pemahaman dari siswa maka proses pembelajaran tidak terjadi. Jika guru berhasil dalam mengkomunikasikan pengetahuannya, maka pengetahuan itu akan menjadi pengetahuan pribadi siswa dan dengan tafsiran dari pengalaman inilah yang nantinya akan menjadi pengetahuan mereka.

Alasan lain dibalik keberhasilan modul pembelajaran berbasis konstruktivisme dapat meningkatkan hasil belajar siswa juga dikarenakan oleh tidak terlepasnya dari karakteristik modul berbasis konstruktivisme itu sendiri dalam memfasilitasi siswa dalam memperoleh pengetahuan. Dalam pembelajaran konstruktivisme siswa yang harus aktif mencari, membangun dan mengembangkan pengetahuan kognitifnya dan bertangguing jawab terhadap hasil belajarnya, dan guru hanya sebagai fasilitator, menyiapkan kondisi, iklim lingkungan, alat dan sarana belajar yang memungkinkan siswa termotivasi belajar secara mandiri untuk lebih aktif dan kreatif. Di satu sisi, Modul merupakan suatu alat atau sarana pembelajaran yang di dalamnya berupa materi, metode, dan evaluasi yang dibuat secara sistematis dan terstruktur sebagai upaya untuk mencapai tujuan kompetensi yang diharapkan. Dalam hal ini, Modul dirancang secara khusus dan jelas berdasarkan kecepatan pemahaman masing-masing siswa, sehingga mendorong siswa untuk belajar sesuai dengan kemampuanya. Menurut Dahar (1989) modul adalah sebuah buku yang ditulis dengan tujuan supaya peserta didik dapat belajar mandiri tanpa bimbingan guru, sehingga modul berisi paling tidak komponen dasar bahan ajar yang telah disebutkan sebelumnya. Hal ini membuat siswa dituntut untuk belajar mandiri agar menambah motivasi belajar dan hasil belajar. Disatu sisi, motivasi sangat berpengaruh terhadap proses dan hasil belajar siswa. Penelitian yang dilakukan Didik, dkk (2019) menemukan bahwa motivasi belajar peserta didik sangat baik jika menggunakan modul. Peserta didik juga memiliki perhatian, ketertarikan, kepuasan, dan percari yang sangat baik dalam menggunakan modul sebagai bahan ajar.

\section{SIMPULAN}

Berdasarkan temuan penelitian pengembangan modul pembelajaran berbasis konstruktivisme yang telah dilakukan, maka diperoleh kesimpulan sebagai yaitu modul pembelajaran berbasis konstruktivisme pada mata pelajaran Sistem Komputer pada siswa kelas X di SMKN 1 Painan berhasil dikembangkan. Berdasarkan uji efektifitas yang telah dilakukan, modul pembelajaran berbasis konstruktivisme yang dikembangkan efektif digunakan pada mata pelajaran Sistem Komputer pada siswa kelas X ditingkat SMK. 


\section{DAFTAR PUSTAKA}

Abdi. (2013). Meningkatkan Kemampuan Siswa Sekolah Menengah Atas dalam Menyelesaikan Soal Matematika Setara Pisa Melalui Pendekatan Konstruktivisme. Artikel Yang Dipublikasikan.

Ahmad. (2011). Hakikat Pendidikan. Jakarta: Rineka Cipt.

Anwar, I. (2010). Pengembangan Bahan Ajar. Bandung: Direktori UPI.

Ariana, \& Dkk. (2020). Pengembangan Modul Berbasis Discovery Learning Pada Materi Jaringan Tumbuhan Untuk Meningkatkan Kemampuan Literasi Sains Siswa Kelas Xi IPA SMA. Jurnal Pendidikan Matematika Dan IPA, 11(1), 34-46.

Arifin. (2011). Belajar dan Faktor yang Mempengaruhinya (Rineka Cip). Jakarta.

Azwar. (2012). Teknik Analisis Untuk Peneliti Pemula. Yogyakarta: Ombak.

Budiyani. (2009). Efektivitas Pendekatan Konstruktivisme dalam Pembelajaran Matematika Ditinjau Dari Aktivitas Belajar Siswa SMP.

Dahar. (1989). Konstruktivisme dalam Pembelajaran. Yogyakarta: Ombak.

Daryanto. (1993). Media Visual untuk Pengajaran Teknik (Tarsito, Ed.). Bandung.

Didik, \& dkk. (2019). Pengembangan Modul Pembelajaran Sistem Reproduksi Berazaskan Al-Quran/Hadis Untuk Meningkatkan motivasi Dan Hasil Belajar Peserta Didik. Jurnal Edusains, 11(1), 132-140.

Gita, Samara, D. (2018). Pengembangan Modul Ipa Materi Hubungan Makhluk Hidup Dan Lingkungannya Berbasis Pendekatan Kontekstual. Jurnal Pendidikan IPA, 8(1), 2837.

Herman. (2012). Pendidikan dan Pengajaran. Yogyakarta: Media Abadi.

Karli. (2003). Efektivitas Pembelajaran. Yogyakarta: AKY Pres.

Karwono. (2017). Belajar dan Pembelajaran. Jakarta: Rineka Cipta.

Kolin, \& Dkk. (2018). Pengembangan Modul Berbasis Keterampilan Proses Sains (Kps) Pada Materi Sistem Organisasi Kehidupan Tingkat Sel. Jurnal Pendidikan Biologi Dan Sains, 1(2), 163-176.

Mulyana, \& Dkk. (2015). Peran Motivasi Belajar, Self-Efficacy, dan Dukungan Sosial Keluarga Terhadap Self-Regulated Learning pada Siswa. Retrieved March 23, 2020, from https://www.e-jurnal.com/2017/06/peran-motivasi-belajar-self-efficacy.html

Sa idah, \& Yulistianti. (2018). Pengembangan Modul Praktikum Berbasis Analisis Data Pada Mata Kuliah Statistik Dalam Meningkatkan Belajar Mandiri Mahasiswa. Jurnal Kreano, 198-203.

Setiyadi, M, D. (2017). Pengembangan Modul Pembelajaran Biologi Berbasis Pendekatan Saintifik Untuk Meningkatkan Hasil Belajar Siswa. Journal of Educational Science and Technology, 3(2), 102-112.

Sriwahyuni, D. (2019). Pengembangan Bahan Ajar Elektronik Menggunakan Flip Pdf Professional Pada Materi Alat-Alat Optik Di SMA. Jurnal Kumparan Fisika, 2(3), 


\section{$145-152$.}

Suryanda, \& Dkk. (2016). Pengembangan Modul Multimedia Mobile Learning Dengan Android Studio 4.1 Materi Keanekaragaman Hayati Bagi Siswa Sma Kelas X. Jurnal Pendidikan Biologi, 9(1), 55-64. 